The

Death of

Authentic

Primitive

Art and

Other

Tales of

Progress 



\title{
The
}

\section{Death of}

\section{Authentic}

\section{Primitive}

\author{
Art and
}

Other

Tales of

Progress

SHELLY

ERRINGTON 
University of California Press

Berkeley and Los Angeles, California

University of California Press, Ltd.

London, England

(C) 1998 by

The Regents of the University of California

The epigraph by M. M. Bakhtin is reprinted from The Dialogic Imagination: Four Essays by M. M. Bakhtin, edited by Michael Holquist, translated by Caryl Emerson and Michael Holquist, Copyright (c) 1981. By permission of the University of Texas Press.

In addition, the author wishes to thank the respective editors and publishers for permission to reuse, in revised form, her previous articles: "Progressivist Stories and the PreColumbian Past: Notes on Mexico and the United States," in Collecting the Pre-Columbian Past, edited by Elizabeth Boone (Washington, D.C.: Dumbarton Oaks, 1993); "Making Progress on Borobudur: A New Perspective," Visual Antropology 9, no. 2 (1993); and "What Became Primitive Art?" Cultural Anthropology 9, no. 2 (1994).

Library of Congress Cataloging-in-Publication Data

Errington, Shelly, 1944-

The death of authentic primitive art and other tales of progress /

Shelly Errington.

p. $\mathrm{cm}$.

Includes bibliographical references and index.

ISBN 0-520-21095-6 (alk. paper). - ISBN 0-520-21211-8 (pbk.: alk. paper)

1. Art and anthropology. 2. Art, Primitive. 3. Art and society.

4. Ethnological museums and collections. I. Title.

N72.S6E77 1998

$709^{\prime} .01^{\prime} 1$ - dc21

98-17204

Printed in the United States of America

987654321

The paper used in this publication meets the minimum requirements of American National Standards for Information Sciences-Permanence of Paper for Printed Library Materials, ANSI Z39.48-1984. 
for

Clifford Geertz

and Benedict Anderson 

After the decline of the ancient world, Europe did not know a single cult, a single ritual, a single state or civil ceremony, a single official genre or style serving either the church or the state (hymn, prayer, sacral formulas, declarations, manifestos, etc.) where laughter was sanctioned (in tone, style or language)even in its most watered-down forms of humor and irony. ... Laughter remained outside official falsifications, which were coated with a layer of pathetic seriousness. Therefore all high and serious genres, all high forms of language and style, all mere set phrases and all linguistic norms were drenched in conventionality, hypocrisy and falsification. Laughter alone remained uninfected by lies.

M. M. BAKHTIN 
